\title{
Technology of Double Thermal Insulation for the Repair and Energy Optimization of Existing Thermal Insulation Composite Systems
}

\author{
Barbora Belániová, Nad'a Antošová \\ Slovak University of Technology in Bratislava, Slovakia \\ Faculty of Civil Engineering, Department of Building Technology \\ e-mail: barbora.belaniova@stuba.sk,nada.antosova@stuba.sk,
}

\begin{abstract}
The theme of improvement thermal proprieties of external cladding according to the New EU Directive is still a hot topic, which needs to be answered necessarily till December 2020. Maintenance and repair of existing ETICS became to also an actual open theme in search solutions for existing constructions. The aim of the research in this review is to analyze influence of layers the alternative thermal materials in technology "double thermal insulation". Humidity and temperature conditions will be further examined in connection with the development and colonization of microorganisms on surface construction.
\end{abstract}

Keywords: thermal insulation, renovation and repair ETICS, microorganisms, vapor pressure.

\section{Introduction}

During 25 years of insulation in Slovakia, several recurring faults of ETICS have been found. They are usually caused by incorrect realizations or projections. There are many incipient faults by [5], [6], especially for excessive tensions in base material below final layer of composite systems.

The most common failures of visual identification are:

- cracks in each direction

- scaling and any mechanical damage

- separation of the plaster surface from the other layers

- separation of the reinforcing layer from the thermal insulation

- contamination by microorganisms and biological attacks on the ETICS layers

The causes of the biological attacks are not exactly known. They are related to several factors. One of the factors are microorganisms in the air, soil and water around us. Another factor is the material base of the plaster. The research shows that ETICS plasters with higher levels of 
acrylates and dispersions are attacked more. The mineral plasters have much better quality as plasters for acrylates and dispersions, those results in longer drying time for surface of the plaster [9]. The long term wet part of plaster is available for the formation of biofilm.

The most efficient protection methods and technologies to remove microorganisms from plaster are direct chemical methods. These methods use toxic effects of chemicals and biocides containing heavy metals to the microorganisms. Technologies for destruction of microorganisms are environmentally burdening their environment, especially water, soil.

They are expensive and also ineffective. Durability of the purification of the plaster from microorganisms is 3 - 5 years [9]. That was limited by biodegradation ETICS, it is necessary to perform cleaning cycles.

\subsection{Repairing ETICS technology double thermal insulation}

A global resolution defect on the surface of ETICS expect technologies to repair the built of ETICS. This technology responds to the increasing requirements of standardized energy performance of buildings (EPBD) 2020 [4].

Table 1: Development of standardized requirement of heat transfer coefficient [2], [7].

\begin{tabular}{|lcccc|}
\hline \multicolumn{1}{|c}{ Building construction } & \multicolumn{4}{c|}{ Boundary conductance $U\left[W / m^{2} \cdot K\right]$} \\
\cline { 2 - 5 } & $\begin{array}{c}\boldsymbol{U}_{\max } \\
\text { od 1.2.1997 }\end{array}$ & $\begin{array}{c}\boldsymbol{U}_{\boldsymbol{n}} \\
\text { od 1.1.2013 }\end{array}$ & $\begin{array}{c}\boldsymbol{U}_{\boldsymbol{N}}=\boldsymbol{U}_{\boldsymbol{r} \mathbf{1}} \\
\text { od 1.1.2016 }\end{array}$ & $\begin{array}{c}\boldsymbol{U}_{\boldsymbol{N}}=\boldsymbol{U}_{\boldsymbol{r} \mathbf{2}} \\
\text { od 1.1.2021 }\end{array}$ \\
\hline External Cladding & 0,46 & 0,32 & 0,22 & 0,15 \\
\hline Ceiling above the exterior & 0,30 & 0,20 & 0,15 & 0,10 \\
\hline
\end{tabular}

Additional improvement of the ETICS thermal properties can be realised by double thermal insulation [7]. The essence of "doubling" is adding another thermal insulation layer, reinforcing layer and new plaster, the best mineral plaster. In projection of "doubling" ETICS we have to proceed so that all requirements [1] will be completed and also [2] with new requirements for the fire protection. A new plaster on double thermal insulation has to have modified properties that can reduce the risk of biological attack ETICS surface.

Thermal insulation contact systems can be designed and built on the base of EPS and MW, which meet the requirements [1], and that demonstrate their interaction with the system of duplication [7]. There are insulating materials based on polyurethanes on the market. To double insulation we can use smaller thickness boards with their properties (thermal insulation and diffusion properties). Negative impact on the illumination of room can be significantly reduced. On aim of this research was to analyze the alternative solutions of a thermal insulation layer in the construction of double thermal insulation. 

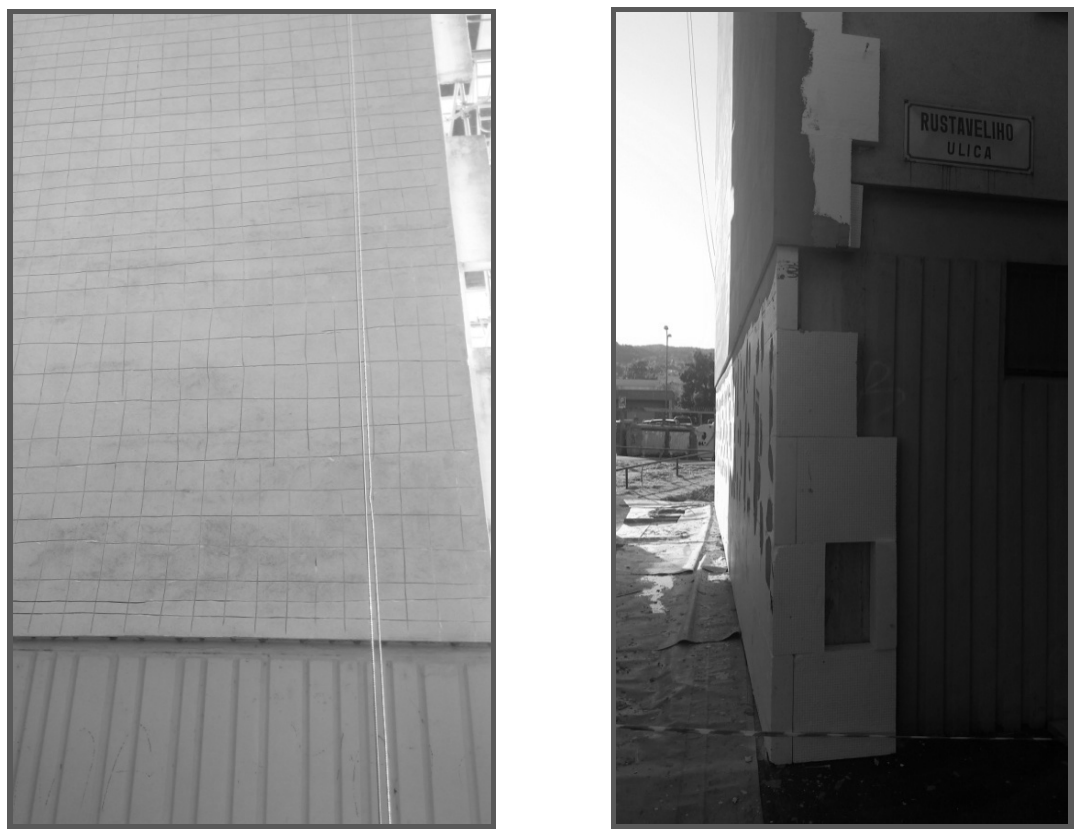

Figure 1: Implementation of double thermal insulation - apartment block Bratislava Rača. On the left is preparation base. On the right is fitting of ETICS double skin construction.

\subsection{Research methodology}

The principles of double thermal insulation show that the new insulating material has to be the same or better diffusion of properties than the original material. By reckoning [7] on Slovakia is $85-90 \%$ ETICS insulated with expanded polystyrene (EPS). Therefore, the research was a reason for using the thermal insulation from polystyrene and the original external cladding panel construction BA-BC, which it has a high representation in Slovakia [8].

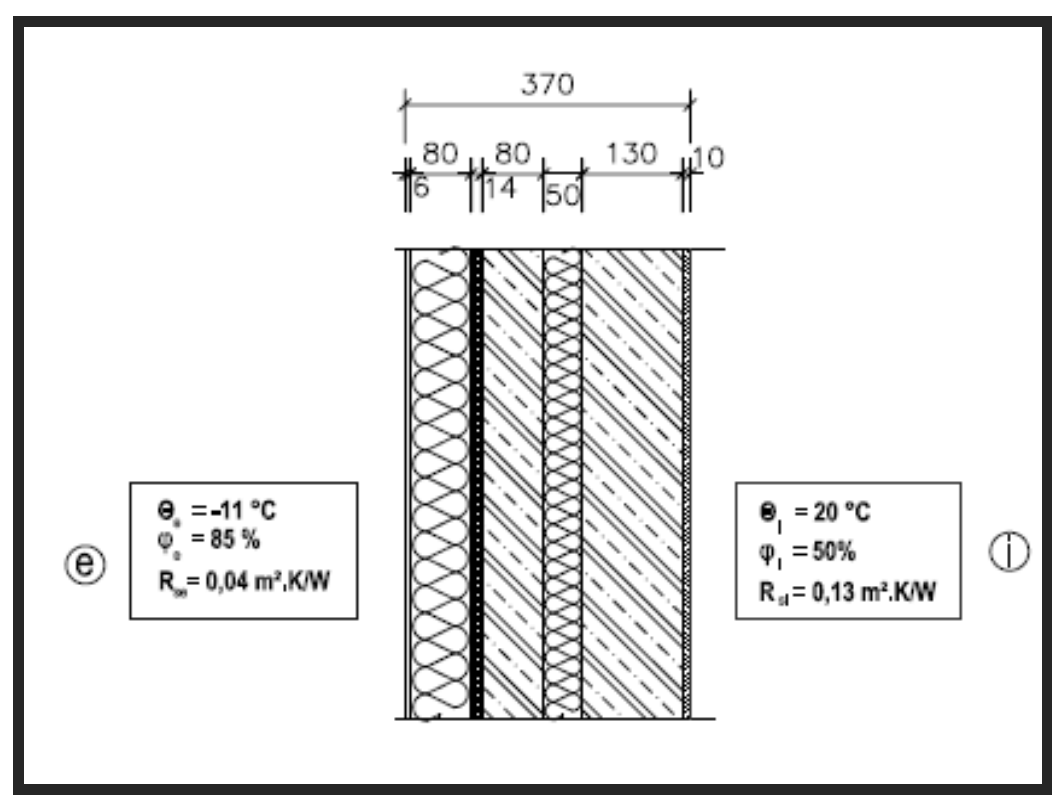

Figure 2: Track construction thermal insulation of apartment block the public housing (panel system BA-BC). Prepared by [8] 
The subject of the research was to detect differences in the thermal-technical and humidity parameters of double skin construction:

- with the thermal insulation from polystyrene

- with the thermal insulation based on polyurethane foam.

The first step was to analyse properties in different thermal insulations in composition of double contact thermal insulation system (table 1 and table 2 ).

Table 2: Properties of materials used in the composition of the double thermal insulation system (EPS polystyrene) Prepared by [11]

\begin{tabular}{|c|c|c|c|c|c|c|c|c|}
\hline \multicolumn{9}{|c|}{ Thermal performance of building materials } \\
\hline \multirow[t]{3}{*}{ č. } & Name of material & Thickness & $\begin{array}{c}\text { Bulk } \\
\text { density }\end{array}$ & K-value & $\begin{array}{l}\text { Specific } \\
\text { thermal } \\
\text { capacity }\end{array}$ & $\begin{array}{l}\text { Factor diffusion } \\
\text { resistance }\end{array}$ & $\begin{array}{l}\text { Thermal } \\
\text { resistance }\end{array}$ & $\begin{array}{c}\text { Diffusion } \\
\text { resistance }\end{array}$ \\
\hline & Symbol & $d$ & $\rho$ & $\lambda$ & $\mathrm{c}$ & $\mu$ & $\mathrm{R}$ & Rd. $10^{9}$ \\
\hline & Unit of measure & $\mathrm{m}$ & $\mathrm{kg} / \mathrm{m}^{3}$ & $\mathrm{~W} /(\mathrm{m} . \mathrm{K})$ & $\mathrm{J} /(\mathrm{kg} . \mathrm{K})$ & $(-)$ & $\mathrm{m}^{2} . \mathrm{K} / \mathrm{W}$ & $\mathrm{m} / \mathrm{s}$ \\
\hline 1 & Line Plaster & 0.010 & 2000 & 0.99 & 790 & 19 & 0.010 & 1.009 \\
\hline 2 & Reinforced Concrete Panel & 0.130 & 2300 & 1.43 & 1020 & 23 & 0.091 & 15.883 \\
\hline 3 & Expanded polystyrene & 0.050 & 20 & 0.044 & 1270 & 50 & 1.136 & 13.280 \\
\hline 4 & Reinforced Concrete Panel & 0.080 & 2300 & 1.43 & 1020 & 23 & 0.056 & 9.774 \\
\hline 5 & Line Plaster & 0.010 & 2000 & 0.99 & 790 & 19 & 0.010 & 1.009 \\
\hline 6 & WEBER.THER EXCLUSIVE & 0.004 & 1220 & 0.84 & 860 & 30 & 0.005 & 0.637 \\
\hline 7 & Expanded polystyrene & 0.080 & 40 & 0.035 & 1270 & 53 & 2.286 & 22.523 \\
\hline 8 & WEBER.THER EXCLUSIVE & 0.004 & 1220 & 0.84 & 1020 & 29 & 0.005 & 0.616 \\
\hline 9 & Reinforcing Grid & - & - & - & - & - & - & - \\
\hline 10 & Primer WEBER 700 & - & - & - & - & - & - & - \\
\hline 11 & WEBER.PAS EXCLUSIVE & 0.002 & 1800 & 0.86 & 920 & 40 & 0.002 & 0.425 \\
\hline 12 & WEBER. THER EXCLUSIVE & 0.004 & 1220 & 0.84 & 1020 & 29 & 0.005 & 0.616 \\
\hline 13 & EPS Expanded polystyrene & 0.060 & 40 & 0.038 & 1270 & 53 & 1.579 & 16.892 \\
\hline 14 & WEBER.THER EXCLUSIVE & 0.004 & 1220 & 0.84 & 1020 & 29 & 0.005 & 0.616 \\
\hline 15 & Reinforcing Grid & - & - & - & - & - & - & - \\
\hline 16 & Primer WEBER 700 & - & - & - & - & - & - & - \\
\hline \multirow[t]{2}{*}{17} & Weber.MIN & 0.002 & 1510 & 0.47 & 850 & 15 & 0.004 & 0.159 \\
\hline & & & & & & $\sum \mathbf{R}$ & 5.194 & 83.44 \\
\hline
\end{tabular}

In the first alternative, in the double thermal insulation (Double ETICS) calculated properties with thermal insulation from polystyrene. Bulk density is the $40 \mathrm{~kg} / \mathrm{m} 3$ and the diffusion resistance factor is the 53 .

The second alternative was in the construction of double thermal insulation material from polyurethane boards. The thermal insulation based on polyurethane has a bulk density of the $34 \mathrm{~kg} / \mathrm{m} 3$ and diffusion resistance factor has the 20. 
Table 3: Properties of materials used in the composition of the double thermal insulation system insulation (TPD-polyurethane boards) Prepared by [10]

\begin{tabular}{|c|c|c|c|c|c|c|c|c|}
\hline \multicolumn{9}{|c|}{ Thermal performance of building materials } \\
\hline \multirow{3}{*}{ č. } & Name of material & Thickness & Bulk density & K-value & $\begin{array}{l}\text { Specific thermal } \\
\text { capacity }\end{array}$ & $\begin{array}{l}\text { Factor diffusion } \\
\text { resistance }\end{array}$ & $\begin{array}{l}\text { Thermal } \\
\text { resistance }\end{array}$ & $\begin{array}{l}\text { Diffusion } \\
\text { resistance }\end{array}$ \\
\hline & Symbol & $d$ & $\rho$ & $\lambda$ & $\mathrm{c}$ & $\mu$ & $\mathrm{R}$ & $\mathrm{Rd} .10^{9}$ \\
\hline & Unit of measure & $\mathrm{m}$ & $\mathrm{kg} / \mathrm{m}^{3}$ & $\mathrm{~W} /(\mathrm{m} . \mathrm{K})$ & $\mathrm{J} /(\mathrm{kg} . \mathrm{K})$ & $(-)$ & $\mathrm{m}^{2} . \mathrm{K} / \mathrm{W}$ & $\mathrm{m} / \mathrm{s}$ \\
\hline 1 & Line Plaster & 0.010 & 2000 & 0.99 & 790 & 19 & 0.010 & 1.009 \\
\hline 2 & Reinforced Concrete Panel & 0.130 & 2300 & 1.43 & 1020 & 23 & 0.091 & 15.883 \\
\hline 3 & Expanded polystyrene & 0.050 & 20 & 0.044 & 1270 & 50 & 1.136 & 13.280 \\
\hline 4 & Reinforced Concrete Panel & 0.080 & 2300 & 1.43 & 1020 & 23 & 0.056 & 9.774 \\
\hline 5 & Line Plaster & 0.010 & 2000 & 0.99 & 790 & 19 & - & - \\
\hline 6 & WEBER.THER EXCLUSIVE & 0.004 & 1220 & 0.84 & 860 & 30 & 0.005 & 0.637 \\
\hline 7 & Expanded polystyrene & 0.080 & 30 & 0.035 & 1270 & 60 & 2.286 & 25.498 \\
\hline 8 & Reinforcing Grid & - & - & - & - & - & - & - \\
\hline 9 & Primer WEBER 700 & - & - & - & - & - & - & - \\
\hline 10 & WEBER.PAS EXCLUSIVE & 0.002 & 1800 & 0.86 & 920 & 40 & 0.002 & 0.425 \\
\hline 11 & NEW-THERM ST04 & 0.004 & 1300 & 0.20 & - & 20 & 0.020 & 0.425 \\
\hline 12 & Thermal Insulation boards TPD - PUR & 0.040 & 34 & 0.022 & - & 20 & 1.818 & 4.250 \\
\hline 13 & NEW-THERM ST04 & 0.004 & 1300 & 0.20 & - & 20 & 0.020 & 0.425 \\
\hline 14 & Leno fiberglass fabric R 117 A 1017 & 0.005 & 0.145 & - & - & - & - & - \\
\hline 15 & NEW-THERM® PGM & 0.001 & 1500 & - & - & - & - & - \\
\hline \multirow[t]{2}{*}{16} & NOVALITH - covering plaster & 0.002 & 1900 & 0.70 & - & 40 & 0.002 & 0.319 \\
\hline & & & & & & $\sum \mathbf{R}$ & 5.446 & 145.188 \\
\hline
\end{tabular}

The proposal thickness insulation follows:

- Alternative I: The minimum thickness thermal insulation of EPS in achieving the standard requirements of $\mathrm{U}_{\mathrm{N}}=\mathrm{U}_{\mathrm{r} 2}$ to the year 2020 is $60 \mathrm{~mm}$.

- Alternative II: The minimum thickness thermal insulation of PUR in achieving the standard requirements of $\mathrm{U}_{\mathrm{N}}=\mathrm{U}_{\mathrm{r} 2}$ to the year 2020 is $40 \mathrm{~mm}$.

Assessment of thermal and technical criteria and humidity criteria of such composite construction results from the following figure:
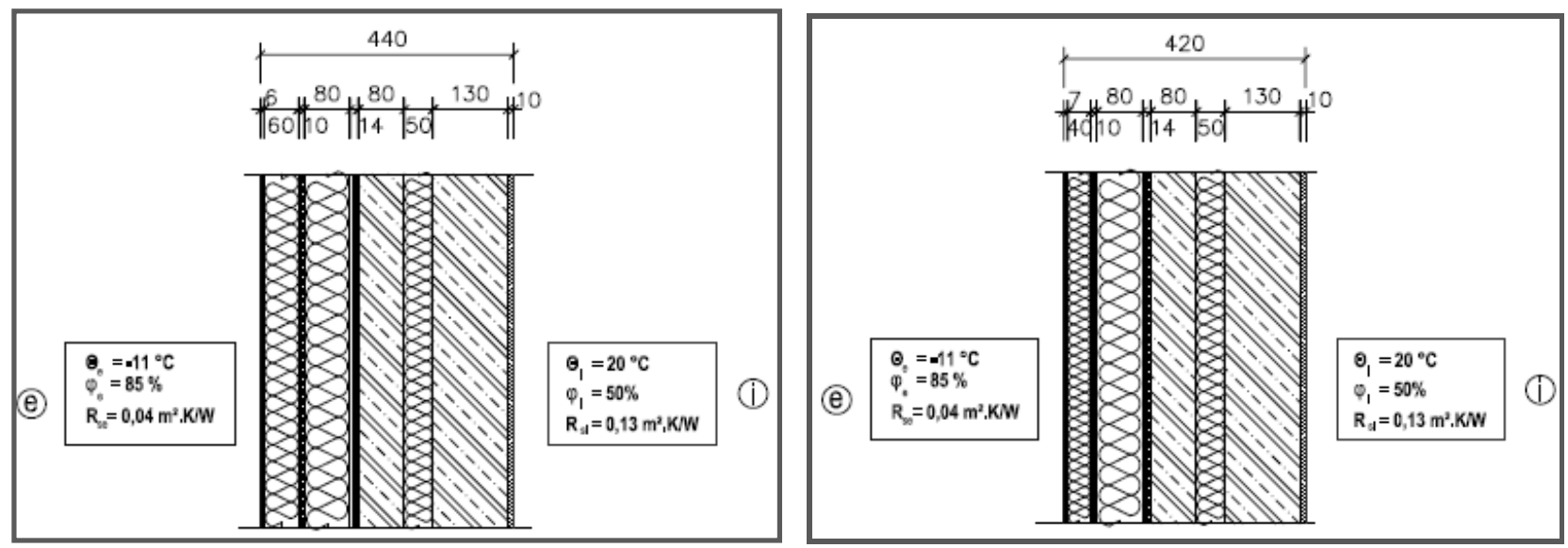

Figure 3: Types "doubling" of structures a) the left insulation of polystyrene b) the right of polyurethane insulation boards. 
Table 4: The results of calculation of thermal-technical properties in the structure of double skin construction (EPS)

\begin{tabular}{|c|c|c|c|c|c|c|c|}
\hline \multicolumn{8}{|c|}{ The results of calculation of thermal properties of structures } \\
\hline \multicolumn{4}{|c|}{ Thermal resistance of structure } & \multicolumn{4}{|c|}{$R=5.36 \mathrm{~m}^{2} . \mathrm{K} / \mathrm{W}$} \\
\hline \multicolumn{4}{|c|}{ Diffusion resistance of structure } & \multicolumn{4}{|c|}{$R_{\mathrm{d}}=83.441 .10^{\wedge} 9 \mathrm{~m} / \mathrm{s}$} \\
\hline \multicolumn{4}{|c|}{ Thermal transmittance } & \multicolumn{4}{|c|}{$U=0.19 \mathrm{~W} /\left(\mathrm{m}^{2} . \mathrm{K}\right)$} \\
\hline \multicolumn{4}{|c|}{ Internal surface temperature } & \multicolumn{4}{|c|}{$\theta_{\mathrm{si}}=18.80^{\circ} \mathrm{C}$} \\
\hline \multicolumn{7}{|c|}{ Design review in terms of thermal properties } & Evaluation \\
\hline Thermal resistance & $R=$ & $5.36 \mathrm{~m}^{2} . \mathrm{K} / \mathrm{W}$ & $>$ & $R_{\mathrm{N}}=$ & $4.40 \mathrm{~m}^{2} . \mathrm{K} / \mathrm{W}$ & $\begin{array}{c}\text { normalized } \\
\text { value }\end{array}$ & PASS \\
\hline Thermal transmittance & $U=$ & $0.19 \mathrm{~W} /\left(\mathrm{m}^{2} . \mathrm{K}\right)$ & $<$ & $U_{N}=$ & $0.22 \mathrm{~W} /\left(\mathrm{m}^{2} . \mathrm{K}\right)$ & $\begin{array}{c}\text { normalized } \\
\text { value }\end{array}$ & PASS \\
\hline The risk of mold & $\theta_{\mathrm{si}}=$ & $18.80^{\circ} \mathrm{C}$ & $>$ & \multicolumn{2}{|c|}{$\theta_{\mathrm{si}, 80}+\Delta \theta_{\mathrm{si}}=$} & $13.10^{\circ} \mathrm{C}$ & PASS \\
\hline
\end{tabular}

Table 5: The results of calculation of thermal-technical properties in the structure of double skin construction (RUR-polyurethane boards)

\begin{tabular}{|c|c|c|c|c|c|c|c|}
\hline \multicolumn{8}{|c|}{ The results of calculation of thermal properties of structures } \\
\hline \multicolumn{4}{|c|}{ Thermal resistance of structure } & \multicolumn{4}{|c|}{$R=5.62 \mathrm{~m}^{2} . \mathrm{K} / \mathrm{W}$} \\
\hline \multicolumn{4}{|c|}{ Diffusion resistance of structure } & \multicolumn{4}{|c|}{$R_{\mathrm{d}}=145.188 .10^{\wedge} 9 \mathrm{~m} / \mathrm{s}$} \\
\hline \multicolumn{4}{|c|}{ Thermal transmittance } & \multicolumn{4}{|c|}{$U=0.18 \mathrm{~W} /\left(\mathrm{m}^{2} . \mathrm{K}\right)$} \\
\hline \multicolumn{4}{|c|}{ Internal surface temperature } & \multicolumn{4}{|c|}{$\theta_{\mathrm{si}}=18.87^{\circ} \mathrm{C}$} \\
\hline \multicolumn{7}{|c|}{ Design review in terms of thermal properties } & Evaluation \\
\hline Thermal resistance & $R=$ & $5.62 \mathrm{~m}^{2} . \mathrm{K} / \mathrm{W}$ & $>$ & $R_{\mathrm{N}}=$ & $4.40 \mathrm{~m}^{2} . \mathrm{K} / \mathrm{W}$ & $\begin{array}{c}\text { normalized } \\
\text { value }\end{array}$ & PASS \\
\hline Thermal transmittance & $U=$ & $0.18 \mathrm{~W} /\left(\mathrm{m}^{2} . \mathrm{K}\right)$ & $<$ & $U_{N}=$ & $0.22 \mathrm{~W} /\left(\mathrm{m}^{2} . \mathrm{K}\right)$ & $\begin{array}{c}\text { normalized } \\
\text { value }\end{array}$ & PASS \\
\hline The risk of mold & $\theta_{\mathrm{si}}=$ & $18.87^{\circ} \mathrm{C}$ & $>$ & \multicolumn{2}{|c|}{$\theta_{\mathrm{si}, 80}+\Delta \theta_{\mathrm{si}}=$} & $13.10^{\circ} \mathrm{C}$ & PASS \\
\hline
\end{tabular}

The analyses of the basic section of double construction results, that if we use to of the polyurethane insulation boards reduces the thickness of the additional thermal insulation on $20 \mathrm{~mm}$

The critical detail for analysing is in the details of doors and windows. [3] Simulation the situation of double thermal insulation in alternative I (EPS boards in thickness $60 \mathrm{~mm}$ ) and alternative II (PUR boards in thickness $40 \mathrm{~mm}$ ) is in the following figure: 


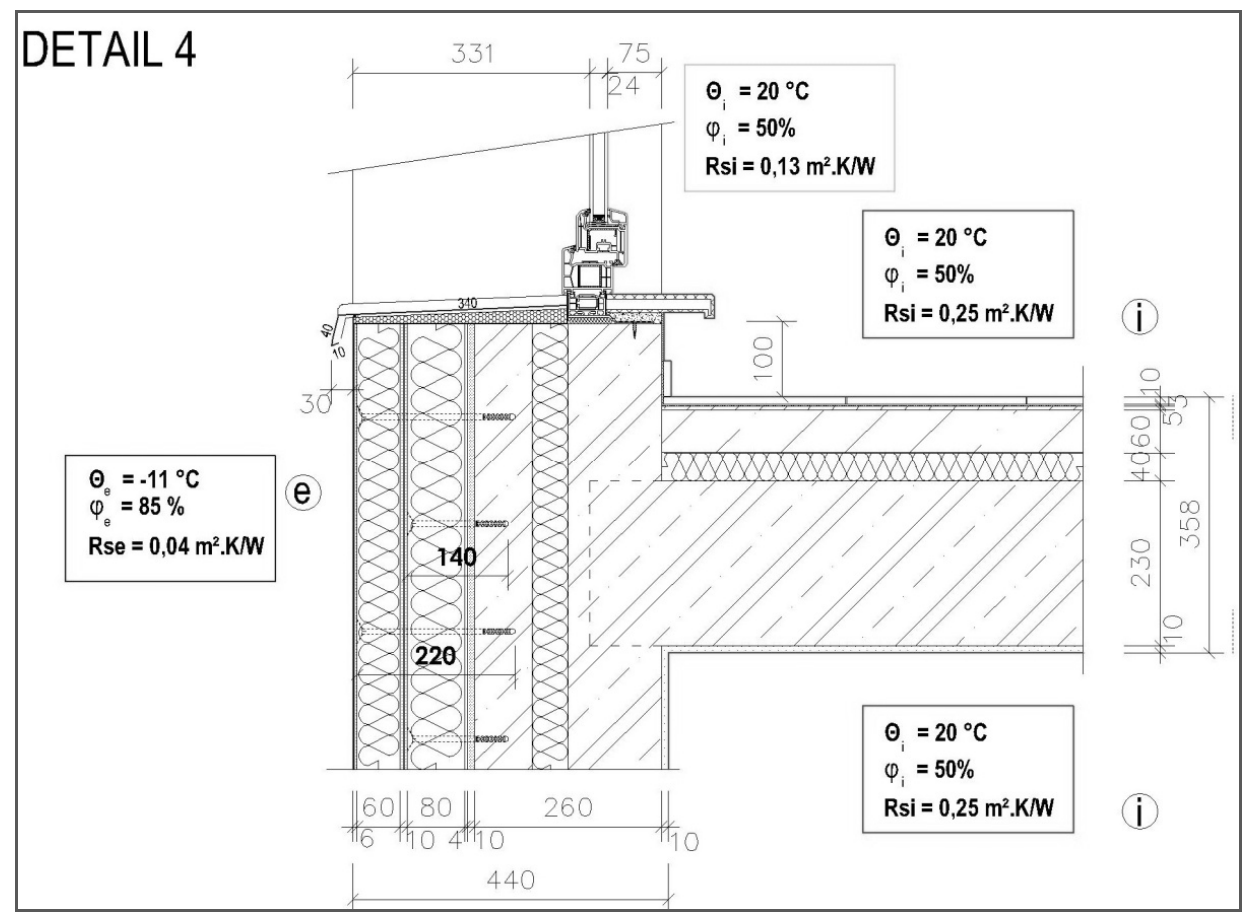

Figure 4: Types double of structures (EPS) and boundary conditions for the model situation. Prepared by to the principles [3].
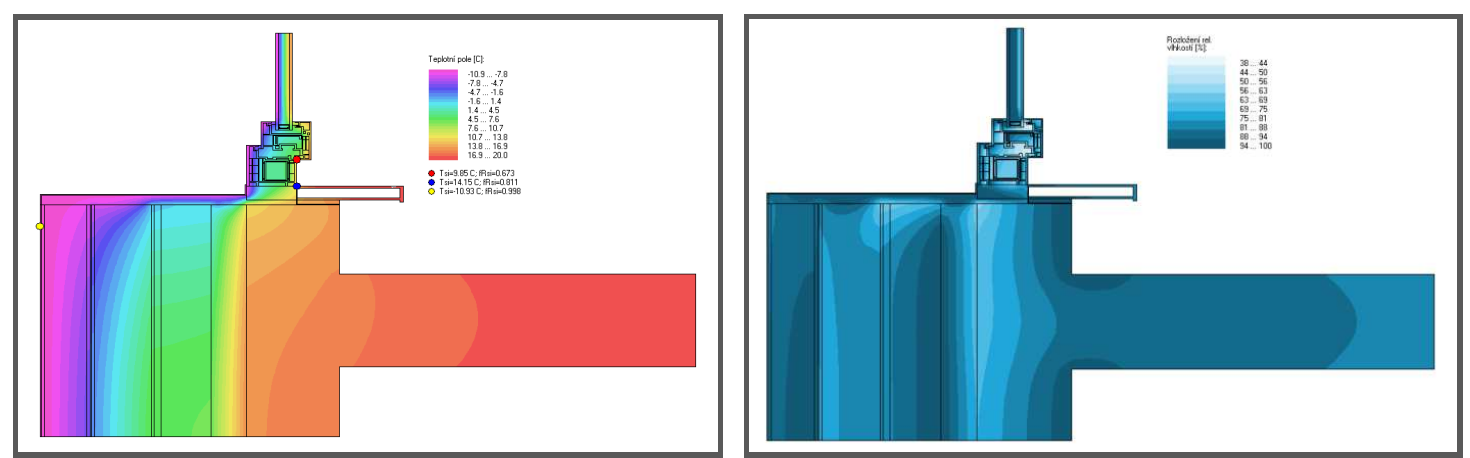

Figure 5: Distribution of temperature and humidity field in the double structure (EPS) windowsill detail. Prepared by [14]
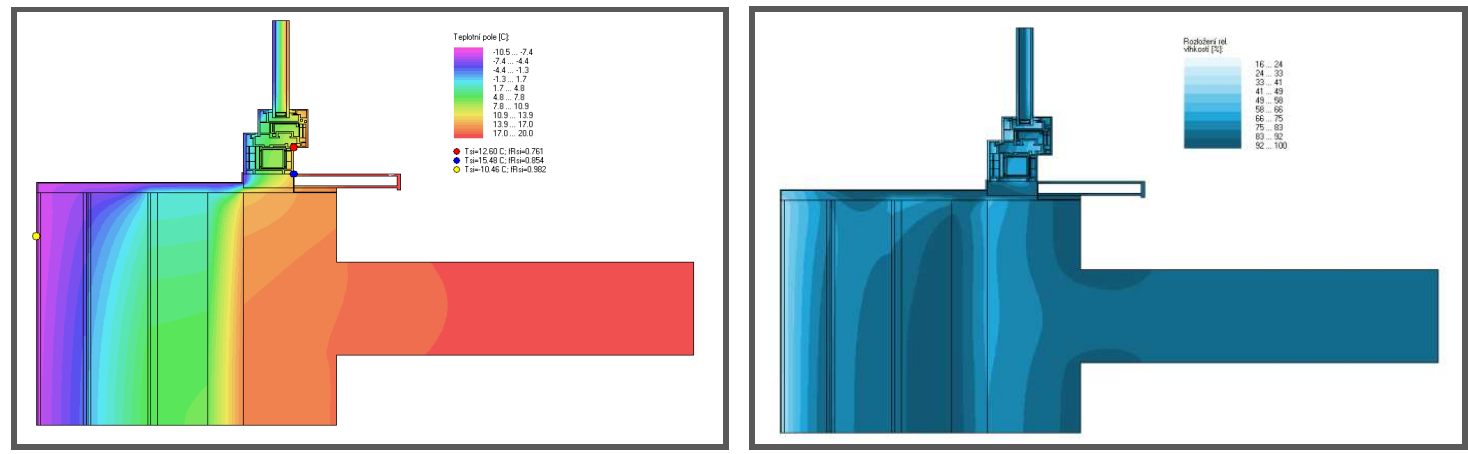

Figure 6: Distribution of temperature and humidity field in the double structure (PUR) windowsill detail. Prepared by [14] 
The further of the research was to detect the distribution of water vapor pressure in typical local construction of double ETICS:

- With the thermal insulation from polystyrene

- With the thermal insulation based on polyurethane foam.

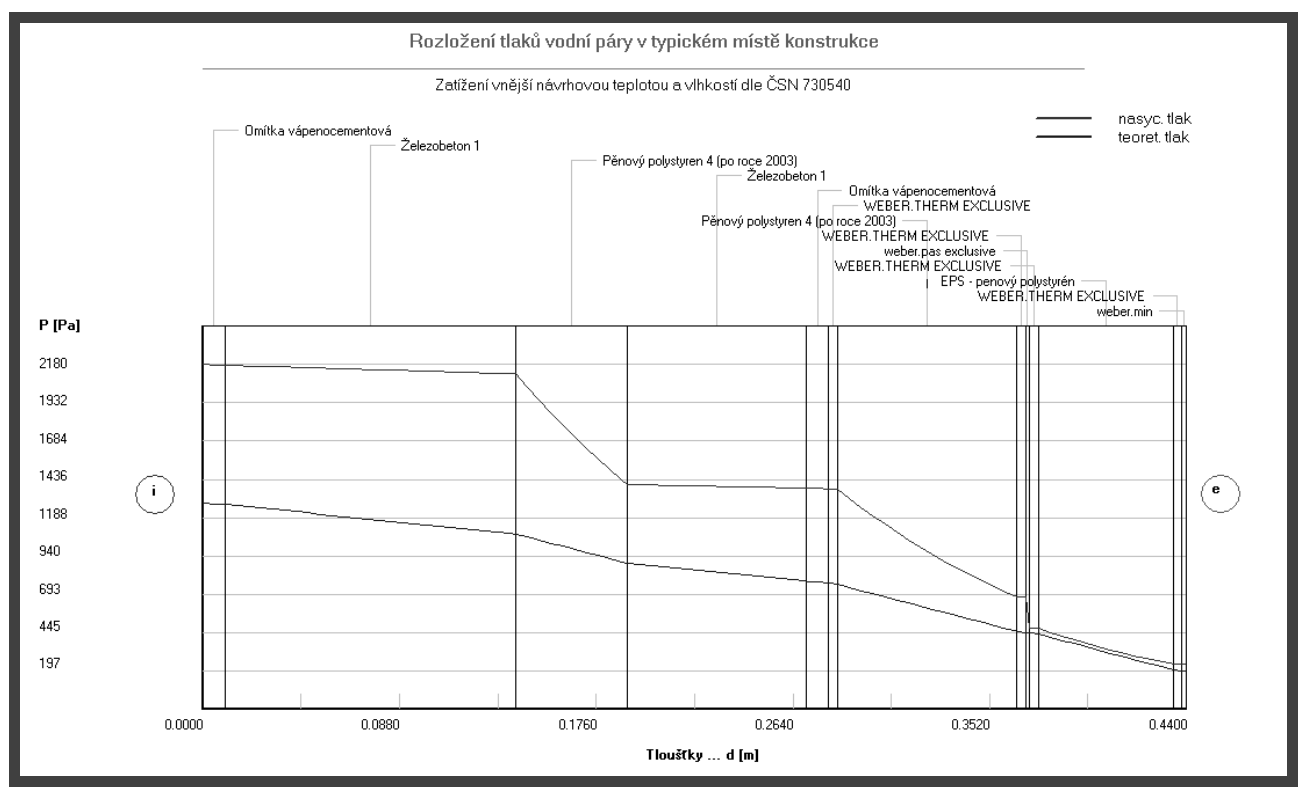

Figure 7: The distribution of water vapor pressure in the construction with the thermal insulation from polystyrene. Prepared by [14].

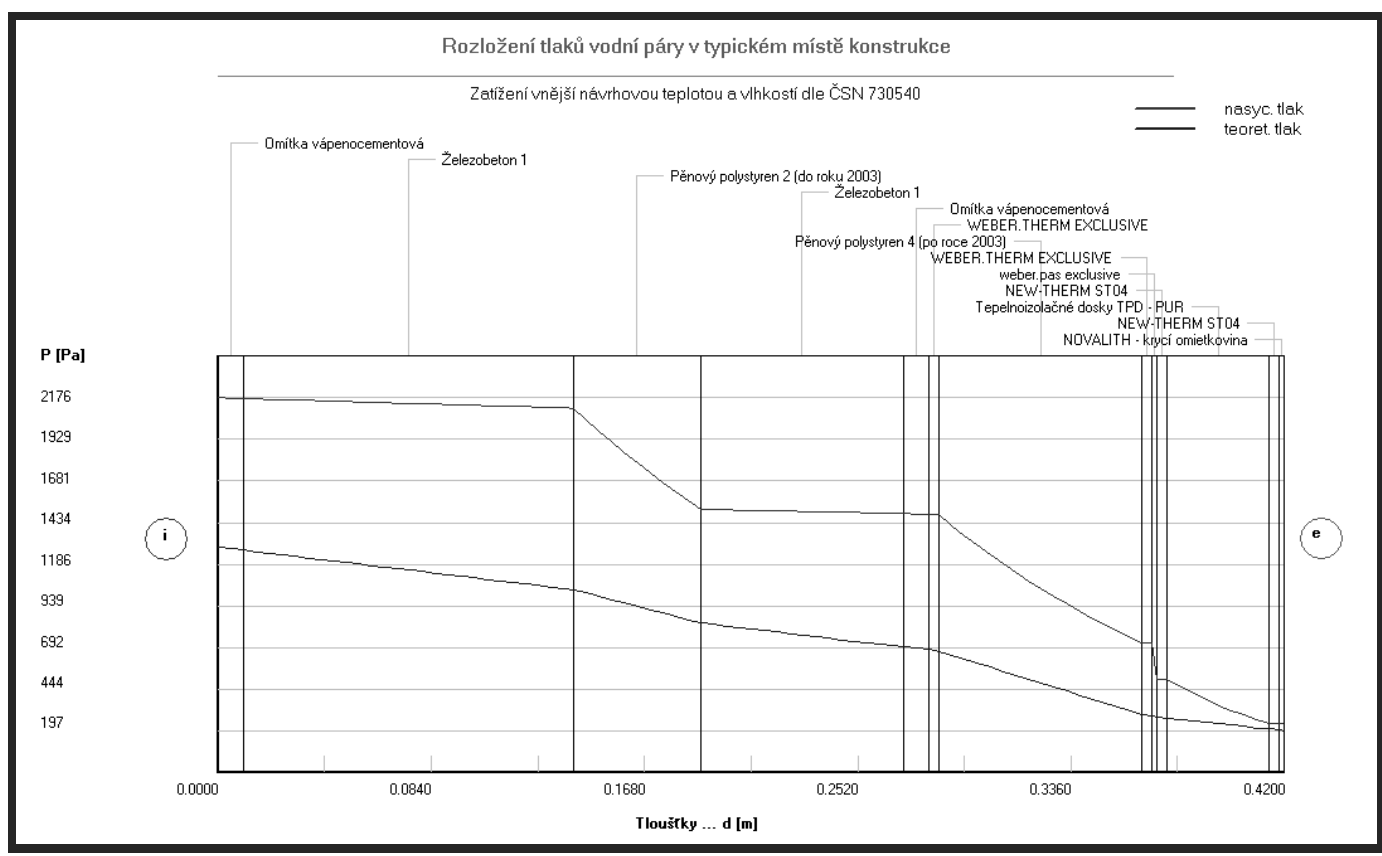

Figure 8: The distribution of water vapor pressure in the construction with the thermal insulation based on polyurethane foam. Prepared by [14].

From review of a typical part in the construction of double thermal insulation shows, that the usage of polystyrene insulation is a considerable supposition condensation of vapor pressure 
in the areas of connection air cavities the original and new thermal insulation. For the thermal isolation from polyurethane foam shows, that the risk is lower.

\subsection{Discussion}

The results of models show the advantages of the design structure for double thermal insulation in alternative II.

The thermal engineering aspect is not the only decision criterion for selecting solutions recovery doubling thermal insulation ETICS. This solution offers less restriction than the sunlit of interior spaces, but objective results require a complete assessment:

1. The assessment of condensation in the composite structure

- recovering biological attack in contact with the original and new ETICS construction

2. The assessment of current regional regulations in fire protection:

- fire barriers to dilatation, around windows and doors at the balconies

3. Technical indicators for the implementation

- weight board, handling ability, storage requirements and so on

4. Economic indicators

- the unit price, labour content and so on

Economic indicators are not used for the total cost of a new ETICS. They are reduced to the basic materials, to which they need to implement the design. Economic indicators must include the cost of transport of the construction site, on workplace and the costs of storage space.

In the alternative II, they can be at a lower thickness thermal insulation and lower weight boards to make interesting numbers. Economic indicators must include the cost of plumbing related construction. A comparison of the total cost of the alternative solutions to the double thermal insulation could be the subject of further research.

Selected economic indicators are processed according to table 6 [12] [13]:

Table 6: Comparison of the cost of the basic material double skin construction

\begin{tabular}{|c|c|c|c|c|}
\hline Double thermal insulation EPS & Type & Width & Length & Price \\
\hline $\begin{array}{l}\text { Aluminium dawn windowsill } 40 \\
\mathrm{~mm}\end{array}$ & RAL9016 & $340 \mathrm{~mm}$ & $2100 \mathrm{~mm}$ & $52,48 €$ \\
\hline $\begin{array}{l}\text { Double thermal insulation PUR } \\
\text { boards }\end{array}$ & Type & Width & Length & Price \\
\hline $\begin{array}{l}\text { Aluminium dawn windowsill } 40 \\
\mathrm{~mm}\end{array}$ & RAL9016 & $320 \mathrm{~mm}$ & $2100 \mathrm{~mm}$ & $51,37 €$ \\
\hline
\end{tabular}

\begin{tabular}{|c|c|c|c|c|c|c|}
\hline \multirow{2}{*}{$\begin{array}{l}\text { Double thermal insulation } \\
\text { EPS }\end{array}$} & \multirow[t]{2}{*}{ Type } & \multirow[t]{2}{*}{ Width } & \multirow{2}{*}{$\begin{array}{l}\text { Size } \\
\text { board }\end{array}$} & \multicolumn{2}{|c|}{ Package } & \multirow{2}{*}{$\begin{array}{l}\text { Price } \\
\left(€ / \mathrm{m}^{2}\right)\end{array}$} \\
\hline & & & & KS & $\mathbf{m}^{2}$ & \\
\hline $\begin{array}{l}\text { EPS - ISOVER - expanded } \\
\text { polystyrene }\end{array}$ & $70 \mathrm{~F}$ & $60 \mathrm{~mm}$ & $\begin{array}{l}1000 \times 500 \\
\mathrm{~mm}\end{array}$ & - & 0,5 & $4,32 € / \mathrm{m}^{2}$ \\
\hline
\end{tabular}




\begin{tabular}{|c|c|c|c|c|c|c|}
\hline \multirow{2}{*}{$\begin{array}{l}\text { Double thermal insulation } \\
\text { PUR boards }\end{array}$} & \multirow[t]{2}{*}{ Type } & \multirow{2}{*}{$\begin{array}{l}\text { Width } \\
(\mathrm{mm})\end{array}$} & \multirow{2}{*}{$\begin{array}{l}\text { Size } \\
\text { board }\end{array}$} & \multicolumn{2}{|c|}{ Package } & \multirow{2}{*}{$\begin{array}{l}\text { Price } \\
\left(€ / \mathrm{m}^{2}\right)\end{array}$} \\
\hline & & & & $\mathbf{K S}$ & $\mathbf{m}^{2}$ & \\
\hline RUR-polyurethane boards & $\begin{array}{l}\text { TPD } \\
\text { PUR }\end{array}$ & $40 \mathrm{~mm}$ & $\begin{array}{l}1000 \times 600 \\
\mathrm{~mm}\end{array}$ & - & 0,6 & $\begin{array}{l}15,00 \\
€ / \mathrm{m}^{2}\end{array}$ \\
\hline
\end{tabular}

\begin{tabular}{|c|c|c|c|c|}
\hline Double thermal insulation EPS & Type & Length & \multicolumn{2}{|l|}{ Price } \\
\hline Insulation anchors - original & KEW - TSD-V & $140 \mathrm{~mm}$ & & $0,40 €$ \\
\hline \multirow[t]{2}{*}{ Insulation anchors - new } & KEW - TSD-V & $220 \mathrm{~mm}$ & & $0,78 €$ \\
\hline & & & Together: & $1,18 €$ \\
\hline $\begin{array}{l}\text { Double thermal insulation PUR } \\
\text { boards }\end{array}$ & Type & Length & Price & \\
\hline Insulation anchors - original & KEW - TSD-V & $140 \mathrm{~mm}$ & & $0,40 €$ \\
\hline Insulation anchors - new & KEW - TSD-V & $200 \mathrm{~mm}$ & & $0,58 €$ \\
\hline & & & $\begin{array}{l}\text { Together: } \\
0,98 €\end{array}$ & \\
\hline
\end{tabular}

\subsection{Summary}

The double thermal insulation technology brings new challenges for ETICS details. The subject for further research will continue with the investigation of water vapor pressure in areas of air cavities between the new and the original isolation. It is a part of a twofold structure which affects the growth, development of micro-cavity area and the degradation of layers in ETICS double skin construction. The whole research is focused on life of technology "double thermal insulation" to compared with chemical cleaning surfaces. The further research will stimulate conditions for the expansion of microorganisms on the building materials and the research of the humidity conditions in connection with the original thermal insulation and with the biotic attack on the surface and new construction of thermal insulation.

\section{References}

[1] STN 73 2901/01: 2015 Zhotovovanie vonkajších tepelnoizolačných kontaktných systémov (ETICS);

[2] STN 73 0540-2: Tepelná ochrana budov. Tepelnotechnické vlastnosti stavebných konštrukcií a budov.

[3] STN 73 3134: 2014 Stavebné práce. Styk okenných konštrukcií a obvodového plášt’a budovy. Požiadavky, zhotovovanie a skúšanie;

[4] Smernica Európskeho parlamentu a Rady č. 2012/27/EÚ o energetickej efektívnosti, ktorou sa menia a dopĺñajú smernice 2009/125/ES a 2010/30/EÚ a ktorou sa zrušujú smernice 2004/8/ES a 2006/32/ES

[5] Blaich, J.: Poruchy stavieb. Bratislava, Vydavatel'stvo JAGA, 2001. ISBN 80-88905-49-4

[6] Šála, J. - Machatka, M.: Zateplováni v praxi, Praha: Grada, 2002, ISBN 80-247-0224-X

[7] Sternová, Z. a kol.: Zásady navrhovania a zhotovovania zdvojenia ETICS. Technická informácia č.3. Bratislava: Jaga group. 2016, ISBN 978-80-8076-126-4

[8] Sternová, Z. a kol.: Obnova bytových domov. Hromadná bytová výstavba do roku 1970. Bratislava: Jaga group. 2001 
[9] Antošová, N. Analýza poznania príčin a technológií riešení biokorózie ETICS a model zabezpečenia ich rezistencie. 1. vyd. Bratislava : Slovenská technická univerzita v Bratislave, 2014. 122 s. ISBN 978-80-227-4302-0

[10] Technický list TPD PUR30/40, Výrobca PCC Moravia. Dostupné: http://www.newtherm.czl

[11] Technický list EPS FS 70, Výrobca ISOVER - Saint-Gobain Construction Products, s.r.o. Dostupné: http://www.isover.sk/

[12] Dostupné: http://www.nonstopstavebniny.sk/sk/e-shop/412310/c13113-tanierovehmozdiny/hmozdina-kew-tsd-v-8x100mm.html

[13] Dostupné: http://www.najlepsie-parapety.sk/hlinikove-tahane-parapety-40-mm/

[14] Tepelné posudky softvér Svoboda Area a Teplo študentská verzia. 
